\title{
Effect of soyabean meal, rapeseed meal and extruded field bean seeds on duodenal amino acids supply in sheep
}

\section{Urbaniak ${ }^{1}$, H. Król ${ }^{1}$, B. Zawadzka', M. Kulik ${ }^{1}$, A. Frankiewicz ${ }^{1}$, A. Łyczyński ${ }^{2}$ E. Pospiech ${ }^{3}$ and Z. Wasilewski ${ }^{1}$}

\author{
August Cieszkowski Agricultural University, \\ 'Department of Animal Nutrition and Feed Management \\ 2Department of Animal Raw Materials \\ ${ }^{3}$ Institute of Meat Technology \\ Wolynska 33, 60-637 Poznañ. Poland
}

(Received 3 August 2000; revised version 6 April 2001; accepted 7 August 2001)

\begin{abstract}
In the first of two experiments, four rumen cannulated wethers were used to determine the extent of rumen protein degradation in soyabean meal (SBM), rapeseed meal (RSM) and extruded field bean seeds (EFB), using the in sacco method. Rumen non-degradable N in SBM, RSM and EFB of total-N was 38,29 and $48 \%$, respectively. In the second experiment, four rams with cannulas in the duodenum were fed isoenergetic total mixed rations (TMR) containing similar amounts of protein truly digestible in the small intestine (PD1). TMR consisted of meadow hay and concentrate (50:50, DM basis) in which SBM, SBM+RSM and SBM+EFB were the main sources of protein.

The highest, statistically significant $(P<0.05)$ methionine and cystine concentrations in the duodenal digesta were found in sheep fed SBM+RSM diet, while the lowest - in those fed SBM+EFB dict. Significantly higher $(P<0.05)$ flows of total N $(33.49 \mathrm{~g} /$ day $)$, non-ammonia $N(33.08 \mathrm{~g} /$ day $)$ and total amino acid $(197.7 \mathrm{~g} / \mathrm{d})$ were observed in sheep fed rations with SBM + EFB.
\end{abstract}

KEY WORDS: sheep, protein sources, duodenum, amino acids

\section{INTRODUCTION}

The amino acids (AA) flowing into the small intestine of ruminants constitute a sum of three protein fractions - microbial protein synthesized in the rumen, feed protein undegraded in this forestomach and endogenous protein from digestive 
secretions and cell turn-over. The degree to which AA requirements of ruminants are fulfilled will depend primarily on the amount of dietary protein, its source and the extent of its degradation in the rumen (Titgemeyer et al., 1989; Benchaar et al., 1994).

The profile of AA reaching ruminants' small intestine is an important determinant of milk and wool production as well as productivity of growing ruminants (Lynch et al., 1991; Urbaniak, 1995b; Rulquin et al., 1998). However, many research papers reported that AA profile of protein absorbable from the small intestine may not always be optimal for maximal performance of different kinds of ruminant production - milk, growth and wool (Schwab 1994; Metcalf et al., 1996; Rulquin et al., 1998). Several reports indicated that AA pattern may vary considerably depending on the type of diet and source of protein (Titgemeyer et al., 1989; Clark et al., 1992; Urbaniak, 1995a; Henson et al., 1997; Rulquin et al., 1998).

Therefore, the aim of this research was to determine the effect of soyabean meal (SBM), rapeseed meal (RSM) or extruded field bean seeds (EFB) on AA profile and AA flow in the small intestine of sheep fed a hay-based diet.

\section{MATERIAL AND METHODS}

\section{Experiment 1}

Four 8-month old wethers of Polish Merino breed weighing $40 \mathrm{~kg}$ (SE $\pm 4 \mathrm{~kg}$ ) fitted with a rumen cannula were used to determine the extent of rumen degradation of SBM, RSM and EFB protein according to the in sacco method given by Mehrez and Ørskov (1977). Samples of each feed were incubated in the rumen for $6,12,18$ and $24 \mathrm{~h}$. The field bean seeds were processed in a twin-screw extruder (Insta Pro $2000 \mathrm{R}, \mathrm{UK}$ ) at an exit temperature of $160^{\circ} \mathrm{C}$. Commercial SBM and RSM were used in this study. The experiment was not processed statistically.

\section{Experiment 2}

Four 8-month old Polish Merino rams weighing $40 \mathrm{~kg}$ (SE $\pm 4 \mathrm{~kg}$ ) fitted with a re-entrant cannula proximal to the pancreatic-bile duct were used as experimental animals. The expcriment was carried out using a transposition design which comprised three consecutive periods in which animals were fed isocnergetic total mixed rations (TMR) containing SBM, SBM+RSM and SBM+EFB as main sources of protein, respectively.

Experimental animals were fed according to the INRA system (IZ-INRA, 1993). The nutritive value of rations were set up using INWAR ver. 1.0 and INRAtion ver. 2.6. (1994) software systems. All TMRs contained similar amounts of net energy 
(UFL) and protein truly digestible in the small intestine (PDI). TMR consisted of concentrate and meadow hay (50:50, DM basis) which was chopped into $2 \mathrm{~cm}$ pieces, mixed with the concentrate every day morning and in this form offered to animals. The composition of concentrates, TMR chemical composition and nutritive value are given in Tables 1, 2 and 3.

Throughout the experiment the rams were housed in individual cages. The diets of $1180 \mathrm{~g}$ per head/day (DM basis) were split into two equal parts and fed to animals at 07:00 and 19:00 h. Water was supplied to animals at each feeding and the barn was lit $24 \mathrm{~h}$.

Each experimental period consisted of a 10-day initial phase followed by a 24-h collection period. The duodenal digesta was collected quantitatively, meas-

TABLE 1

Composition of the concentrate mixtures, \%

\begin{tabular}{lccc}
\hline Component & \multicolumn{3}{c}{ Supplement } \\
\cline { 2 - 4 } & SBM & SBM+RSM & SBM+EFB \\
\hline Soyabean meal & 31.16 & 20.09 & 20.00 \\
Rapesced meal & - & 20.09 & - \\
Extruded field bean seeds & - & - & 20.00 \\
Wheat & 32.34 & 40.08 & 51.00 \\
Wheat brans & 31.43 & 15.07 & 5.10 \\
Rape seed oil & 2.56 & 2.56 & 1.00 \\
Limestone & 1.60 & 1.21 & 2.00 \\
Mineral-vitamin premix & 0.90 & 0.90 & 0.90 \\
\hline
\end{tabular}

${ }^{1}$ contains in $1 \mathrm{~kg}$ : vit. A $1600000 \mathrm{IU}$, vit. D, $130000 \mathrm{IU}$, vit. E $2000 \mathrm{mg}$, vit. B, $500 \mathrm{mg}$, Fe $2000 \mathrm{mg}$, Cu $1600 \mathrm{mg}, \mathrm{Mn} 8000 \mathrm{mg}$, Zn $9000 \mathrm{mg}$, I $80 \mathrm{mg}$, Co $20 \mathrm{mg}$, Se $30 \mathrm{mg}$, Mg $40 \mathrm{mg}$

TABLE 2

Chemical composition of total mixed rations (TMR), $\mathrm{g} / \mathrm{kg}$ dry matter

\begin{tabular}{lccc}
\hline \multirow{2}{*}{ tem } & \multicolumn{3}{c}{ Supplement } \\
\cline { 2 - 4 } & SBM & SBM+RSM & SBM+EFB \\
\hline Dry matter & 884.1 & 902.2 & 910.0 \\
Crude protein & 158.3 & 186.3 & 140.4 \\
Ether extract & 30.0 & 28.6 & 27.4 \\
Crude fibre & 159.5 & 191.9 & 232.6 \\
N-free extractives & 573.1 & 512.2 & 524.9 \\
Crude ash & 79.1 & 81.0 & 74.7 \\
Acid detergent fibre & 212.9 & 228.1 & 262.5 \\
Neutral detergent fibre & 454.0 & 443.7 & 491.8 \\
\hline
\end{tabular}


TABLE 3

Nutritive valuc of experimental total mixed rations (TMR)

\begin{tabular}{lccc}
\hline Item & \multicolumn{3}{c}{ Supplement } \\
\cline { 2 - 4 } & SBM & SBM+RSM & SBM+EFB \\
\hline In I kg of DM, INRA system: & & & \\
UFL & 0.91 & 0.93 & 0.92 \\
PDI, & 120 & 119 & 114 \\
PDIN & 110 & 109 & 105 \\
PDIE & & & \\
\hline
\end{tabular}

IZ-INRA (1993): UFL - net encrgy, unit for milk production; PDI - protein truly digestible in the small intestine: PDIN - PDI dependent on fermentable $\mathrm{N}$ amount: PDIE - PDI dependent on ruminally available energy amount

ured every three hours, heated to the temperature of $38^{\circ} \mathrm{C}$ and infused to the distal part of the duodenum. Aliquots constituting $5 \%$ of the collected digesta from each animal were then composited and a sub-sample frozen for subsequent analysis of $\mathrm{NH}_{3}-\mathrm{N}$. The remainder of the duodenal composite was lyophilized and ground (2- $\mathrm{mm}$ screen ) for further analyses.

Standard methods were used to determine the chemical composition of feeds and duodenal digesta (AOAC, 1990). Acid detergent fibre (ADF) and neutral detergent fibre (NDF) were determined by the method of Van Soest et al. (1991). The content of $\mathrm{NH}_{3}-\mathrm{N}$ in the duodenal digesta was analysed using Conway method (Conway, 1962). Dry matter of the small intestine digesta was calculated from the difference between the weights of samples before and after lyophilization, while non-ammonia nitrogen (NAN) from the difference between the amount of total-N and $\mathrm{NH}_{3}-\mathrm{N}$. Amino acid composition of feeds and lyophilizates of duodenal digesta were determined using an automatic amino acid analyser (T-339, Mikrotechna, Czech Republic), after hydrolysis with $6 \mathrm{~N} \mathrm{HCL}\left(24 \mathrm{~h}, 105^{\circ} \mathrm{C}\right)$. Methionine and cystine were analysed in samples prepared according the method given by Urbaniak (1995a).

Results were analysed using one-way analysis of variance, with multiple interval test according to Statgraphics Plus 6.0 (1992) software, used to compare treatment means with significant $F$ values.

\section{RESULTS}

\section{Experiment 1}

The ruminal escape $\mathrm{N}$ values determined in this experiment for SBM, RSM and $\mathrm{EFB}$ were 38,29 and $48 \%$, respectively. 


\section{Experiment 2}

The significant $(\mathrm{P}<0.05)$ influence of dietary supplements on duodenal flow of different $\mathrm{N}$ fractions was observed (Table 4). The animals from individual groups consumed different quantities of $\mathrm{N}$, which resulted from both - different crude protein content and differences in the intake of individual feeds. The highest duodenal $\mathrm{N}$ flow was recorded in animals fed SBM + EFB $(33.49 \mathrm{~g} / \mathrm{d})$ and the lowest - in rams given SBM diets $(30.94 \mathrm{~g} / \mathrm{d})$. The recovery of total- $\mathrm{N}$ in the duodenum exceeded $\mathrm{N}$ intake in all experimental diets. The lowest $\mathrm{NH}_{3}-\mathrm{N}$ flow through the duodenum was found in sheep fed the diet containing SBM+EFB $(0.41 \mathrm{~g} / \mathrm{d})$ and the highest in SBM + RSM $(0.77 \mathrm{~g} / \mathrm{d})$. The duodenal flow of NAN was found to differ among treatments. The highest flow of this $\mathrm{N}$ fraction was determined in animals fed SBM + EHB (33.08 g/d) and the lowest in SBM diet $(25.80 \mathrm{~g} / \mathrm{d})$. Rams fed SBM + RSM diets reached intermediate values.

TABLE 4

$\mathrm{N}$ intake and flow through duodenum of total- $\mathrm{N}$, ammonia- $\mathrm{N}\left(\mathrm{NH}_{3}-\mathrm{N}\right)$ and non- ammonia- $\mathrm{N}$ (NAN)

\begin{tabular}{|c|c|c|c|c|}
\hline \multirow{2}{*}{ Item } & \multicolumn{3}{|c|}{ Supplement } & \multirow{2}{*}{$\mathrm{SE}^{\prime}$} \\
\hline & SBM & $\mathrm{SBM}+\mathrm{RSM}$ & $\mathrm{SBM}+\mathrm{EFB}$ & \\
\hline $\mathrm{N}$ intake, $\mathrm{g} /$ day & $20.14^{a}$ & $24.88^{\mathrm{b}}$ & $24.13^{6}$ & 0.73 \\
\hline \multicolumn{5}{|l|}{ Duodenal flow } \\
\hline total $\mathrm{N}, \mathrm{g} /$ day & $26.49^{\circ}$ & $30.94^{6}$ & $33.49^{\circ}$ & 1.80 \\
\hline total $N, \%$ intake & $131.53^{\mathrm{a}}$ & $124.40^{b}$ & $138.79^{\circ}$ & 4.28 \\
\hline $\mathrm{NH}_{3}-\mathrm{N}, \mathrm{g} / \mathrm{day}$ & $0.69^{4}$ & $0.77^{4}$ & $0.41^{b}$ & 0.02 \\
\hline NAN, g/day & $25.80^{\mathrm{a}}$ & $30.17^{\mathrm{h}}$ & $33.08^{\mathrm{b}}$ & 1.29 \\
\hline
\end{tabular}

Dietary protein AA composition (Table 5) expressed as the sum of essential AA (EAA), non-essential AA (NEAA) and total AA (TAA) was similar. However, differences in the content of individual AA were detected. The highest amounts of methionine and cystine ( 1.8 and $1.4 \mathrm{~g} / 16 \mathrm{gN}$, respectively) were found in $\mathrm{SBM}+\mathrm{RSM}$ dicts and the lowest in SBM+EFB rations $(0.8$ and $0.9 \mathrm{~g} / 16 \mathrm{~g} \mathrm{~N}$, respectively). The content of lysine in the protein of all diets was similar.

AA profile of protein absorbable from the small intestine (Table 6) differed from that of the dietary protein AA. The source of protein in TMR influenced the content in duodenum of some EAA - methionine, cystine and histidine as well as tyrosine and glycine. The sum of EAA, NEAA and TAA did not significantly $(\mathrm{P}>0.05)$ differ among treatments. 
TABLE 5

Amino acid composition of diets, $\mathrm{g} / 16 \mathrm{~g} \mathrm{~N}$

\begin{tabular}{lccc}
\hline Amino acid & \multicolumn{3}{c}{ Supplement } \\
\cline { 2 - 4 } & SBM & SBM+RSM & SBM +EFB \\
\hline Essential amino acids & & & \\
Lys & 5.2 & 5.2 & 5.1 \\
His & 2.8 & 3.5 & 2.8 \\
Thr & 3.6 & 3.7 & 3.9 \\
Arg & 5.8 & 3.5 & 5.9 \\
Val & 5.0 & 5.1 & 5.2 \\
Met & 1.1 & 1.8 & 0.8 \\
Cys & 0.9 & 1.4 & 0.9 \\
Ilc & 4.0 & 4.0 & 4.0 \\
Leu & 7.0 & 8.0 & 7.2 \\
Phe & 5.5 & 5.6 & 5.8 \\
& & & \\
Non-essential amino acids & & & 4.1 \\
Tyr & 3.6 & 4.1 & 9.4 \\
Asp & 10.0 & 9.0 & 17.8 \\
Glu & 19.7 & 19.5 & 4.3 \\
Ser & 4.3 & 4.3 & 4.6 \\
Gly & 4.2 & 4.4 & 5.6 \\
Ala & 5.3 & 4.9 & 7.5 \\
Pro & 7.7 & 7.7 & 41.6 \\
Total EAA & & & 53.3 \\
Total NEAA & 40.9 & 51.8 & \\
Total amino acids & 54.8 & 95.7 & \\
\hline
\end{tabular}

Animals from all groups were fed diets containing a similar amount of PDI, but different amounts of crude protein. As feed intake was also different, this caused significant $(\mathrm{P}<0.05)$ differences in AA intake (Table 7). The highest intakes of EAA, NEAA and TAA were observed in animals fed SBM + RSM and the lowest in the group fed SBM. However, the highest $(\mathrm{P}<0.05)$ flow of EAA, NEAA, TAA through duodenum (Table 8) was noted in sheep fed $\mathrm{SBM}+\mathrm{EFB}$, on the other hand the flow of methionine and cystine was lower in the case of this group.

\section{DISCUSSION}

The performed study characterized the effect of SBM, RSM and EFB on the AA profile and the AA flow in the sheep duodenum. Individual protein sources 
TABLE 6

Anino acid composition of duodenal digesta, g/16 g N

\begin{tabular}{|c|c|c|c|c|}
\hline \multirow{2}{*}{ Amino acid } & \multicolumn{3}{|c|}{ Supplement } & \multirow{2}{*}{$\mathrm{SE}$} \\
\hline & SBM & $\mathrm{SBM}+\mathrm{RSM}$ & $\mathrm{SBM}+\mathrm{EFB}$ & \\
\hline \multicolumn{5}{|c|}{ Essential amino acids } \\
\hline Lys & 6.2 & 6.1 & 6.2 & 0.3 \\
\hline $\mathrm{His}$ & $2.7^{\mathrm{a}}$ & $2.6^{\mathrm{a}}$ & $1.9^{b}$ & 0.3 \\
\hline Thr & 5.1 & 5.0 & 4.9 & 0.2 \\
\hline Arg & 4.5 & 3.9 & 3.8 & 0.3 \\
\hline Val & 5.6 & 5.4 & 5.2 & 0.3 \\
\hline Met & $1.4^{\mathrm{a}}$ & $1.9^{b}$ & $1.2^{\mathrm{i}}$ & 0.1 \\
\hline Cys & $1.5^{\natural}$ & $1.7^{\mathrm{a}}$ & $1.2^{\mathrm{b}}$ & 0.1 \\
\hline $\mathrm{Ile}$ & 4.2 & 4.3 & 4.4 & 0.3 \\
\hline Leu & 7.4 & 7.5 & 7.1 & 0.3 \\
\hline Phe & 5.6 & 5.2 & 5.5 & 0.2 \\
\hline \multicolumn{4}{|c|}{ Non-essential amino acids } & \\
\hline Tyr & $4.0^{: !}$ & $4.5^{\mathrm{a}}$ & $5.7^{b}$ & 0.2 \\
\hline Asp & 10.6 & 10.7 & 10.3 & 0.1 \\
\hline Glu & 14.4 & 14.2 & 13.7 & 0.3 \\
\hline Ser & 5.4 & 5.5 & 5.1 & 0.1 \\
\hline Gily & $5.7^{\mathrm{a}}$ & 5.4 & 7.6 & 0.2 \\
\hline $\mathrm{Ala}$ & 6.2 & 6.1 & 6.4 & 0.2 \\
\hline \multicolumn{5}{|l|}{ Pro } \\
\hline Total EAA & 42.4 & 43.6 & 41.4 & 0.6 \\
\hline Total NEAA & 50.7 & 51.3 & 53.1 & 0.7 \\
\hline Total amino acids & 93.1 & 94.9 & 94.5 & 0.6 \\
\hline
\end{tabular}

a.b means in the same row followed by different letters differ at $P<0.05$

differed in the extent of ruminal degradation. The degradability of SBM and RSM crude protein found in sacco method in these investigations were comparably with those reported elsewhere in the literature (Madsen and Hvelplund, 1985; Masoero et al., 1994). The value for EFB ruminal escape $N(48 \%)$ observed in performed experiment was a little higher than in study conducted by Benchaar et al. (1994) and the differences can be attributed to different technological parameters of extrusion.

Total mixed rations applied in the study contained different protein sources. The diets contained similar amounts of PDI, however, the content of crude protein varied and amounted to 158,186 and $140 \mathrm{~g}$ in $1 \mathrm{~kg}$ DM in SBM, SBM+RSM and $\mathrm{SBM}+\mathrm{EFB}$ rations, respectively. These differences and the fact that individual animals consumed varying amounts of feed caused significant differences in total-N intake. 
Amino acid intake from rations, g/day

\begin{tabular}{|c|c|c|c|c|}
\hline \multirow{2}{*}{ Amino acid } & \multicolumn{3}{|c|}{ Supplement } & \multirow{2}{*}{$\mathrm{SE}$} \\
\hline & SBM & $\mathrm{SBM}+\mathrm{RSM}$ & $\mathrm{SBM}+\mathrm{EFB}$ & \\
\hline \multicolumn{5}{|c|}{ Essential amino acids } \\
\hline Lys & $6.5^{\mathrm{Aa}}$ & $8.1^{\mathrm{Bb}}$ & $7.7^{1 \mathrm{k}}$ & 0.2 \\
\hline $\mathrm{His}$ & $3.5^{\mathrm{Aa}}$ & $5.4^{\mathrm{kb}}$ & $4.2^{\wedge \mathrm{c}}$ & 0.1 \\
\hline Thr & $4.5^{\mathrm{a}}$ & $5.7^{\mathrm{b}}$ & $5.9^{\mathrm{bc}}$ & 0.2 \\
\hline Arg & $7.3^{\mathrm{Aa}}$ & $5.4^{\mathrm{Bb}}$ & $8.9^{\wedge c}$ & 0.2 \\
\hline Val & $6.3^{3}$ & $7.9^{\mathrm{a}}$ & $7.8^{\mathrm{b}}$ & 0.2 \\
\hline Met & $1.4^{\mathrm{Au}}$ & $2.8^{\mathrm{Bb}}$ & $1.2^{\wedge a}$ & 0.1 \\
\hline Cys & $1.1^{\mathrm{Aa}}$ & $2.2^{\mathrm{Bh}}$ & $1.3^{\mathrm{Aa}}$ & 0.1 \\
\hline Ile & $5.0^{\mathrm{a}}$ & $6.2^{\mathrm{b}}$ & $6.0^{\mathrm{b}}$ & 0.2 \\
\hline Leu & $8.8^{\mathrm{Aa}}$ & $12.4^{\mathrm{l} b \mathrm{~b}}$ & $10.8^{\mathrm{Bc}}$ & 0.7 \\
\hline Phe & $6.9^{\mathrm{a}}$ & $8.7^{\mathrm{b}}$ & $8.7^{\mathrm{b}}$ & 0.3 \\
\hline \multicolumn{5}{|c|}{ Non-essential amino acids } \\
\hline Tyr & $4.5^{\mathrm{Aa}}$ & $6.4^{\mathrm{Bb}}$ & $6.2^{13 b}$ & 0.2 \\
\hline Asp & $12.6^{a}$ & $14.0^{\mathrm{b}}$ & $14.2^{\mathrm{b}}$ & 0.8 \\
\hline Glu & $24.8^{\mathrm{Aa}}$ & $30.3^{B b}$ & $26.8^{\mathrm{Aa}}$ & 1.2 \\
\hline Ser & $5.4^{\mathrm{a}}$ & $6.7^{\mathrm{b}}$ & $6.5^{b}$ & 0.3 \\
\hline Gly & $5.3^{\mathrm{a}}$ & $6.8^{b}$ & $6.9^{b}$ & 0.2 \\
\hline Ala & $6.7^{\mathrm{a}}$ & $7.6^{\mathrm{ab}}$ & $8.4^{b}$ & 0.4 \\
\hline Pro & $9.7^{\mathrm{Aa}}$ & $12.0^{\mathrm{Bb}}$ & $11.3^{\mathrm{Ab}}$ & 0.5 \\
\hline Total EAA & $51.3^{\mathrm{a}}$ & $64.8^{\mathrm{b}}$ & $62.5^{b}$ & 2.1 \\
\hline Total NEAA & $69.0^{\mathrm{a}}$ & $83.8^{b}$ & $80.3^{b}$ & 3.0 \\
\hline Total amino acids & $120.3^{\mathrm{Al}}$ & $148.6^{\mathrm{tb}}$ & $142.8^{13 b}$ & 5.8 \\
\hline
\end{tabular}

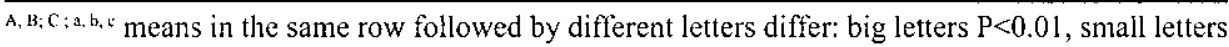
$\mathrm{P}<0.05$

In all treatments the duodenal flow of total- $\mathrm{N}$ was higher than $\mathrm{N}$ intake. The highest value of this parameter was observed in animals fed SBM+EFB and the lowest in sheep obtained SBM+RSM diets. The phenomenon of $\mathrm{N}$ recoveries greater than $100 \%$ has been reported elsewhere. Locrch ct al. (1983) reported increases in $\mathrm{N}$ flow to the duodenum of $18,27,58,59$ and $81 \%$ for diets supplemented with urea, meat meal, soyabean meal, blood meal and dehydrated lucerne, respectively. Similarly, Price et al. (1988) observed that in cows fed dehydrated lucerne, total-N duodenal flow was $11 \%$ higher than intake. In the experiment conducted by Urbaniak (1995a) on sheep, total- $\mathrm{N}$ recovery in the duodenum exceeded $\mathrm{N}$-intake in diets with fish meal, blood meal, and soyabean meal $(133,121$ and $114 \%$, respectively), but with casein - it was slightly lower $(97 \%)$. 
Amino acid flow through sheep duodenum, g/day

\begin{tabular}{|c|c|c|c|c|}
\hline \multirow{2}{*}{ Amino acid } & \multicolumn{3}{|c|}{ Supplement } & \multirow{2}{*}{ SE } \\
\hline & SBM & SBM+RSM & $\mathrm{SBM}+\mathrm{EFB}$ & \\
\hline \multicolumn{5}{|c|}{ Essential amino acids } \\
\hline I.ys & $10.0^{\mathrm{a}}$ & $11.8^{\mathrm{bc}}$ & $13.0^{c}$ & 0.3 \\
\hline His & 4.3 & 5.0 & 4.0 & 0.1 \\
\hline Thr & 8.2 & 9.7 & 10.2 & 0.2 \\
\hline Arg & 6.9 & 7.5 & 7.9 & 0.2 \\
\hline Val & 9.0 & 10.4 & 10.9 & 0.3 \\
\hline Met & $2.3^{\mathrm{a}}$ & $3.7^{\mathrm{b}}$ & $2.5^{\mathrm{a}}$ & 0.1 \\
\hline Cys & $2.4^{4}$ & $3.3^{b}$ & $2.5^{\mathrm{a}}$ & 0.2 \\
\hline lle & $6.8^{\mathrm{a}}$ & $8.3^{b}$ & $9.2^{\mathrm{b}}$ & 0.3 \\
\hline Leu & 11.9 & 14.5 & 14.9 & 0.3 \\
\hline Phe & 9.0 & 10.0 & 11.5 & 0.4 \\
\hline \multicolumn{5}{|c|}{ Non- essential amino acids } \\
\hline Tyr & $6.4^{\circ}$ & $8.7^{\mathrm{b}}$ & $11.9^{\mathrm{c}}$ & 0.2 \\
\hline Asp & 17.1 & 20.7 & 21.5 & 0.1 \\
\hline Glu & $23.2^{a}$ & $27.5^{b}$ & $28.7^{\mathrm{b}}$ & 0.3 \\
\hline Ser & 8.7 & 10.6 & 10.7 & 0.2 \\
\hline Gly & $9.2^{a}$ & $10.4^{\mathrm{a}}$ & $15.9^{\mathrm{b}}$ & 0.2 \\
\hline Ala & $10.0^{\mathrm{a}}$ & $11.8^{\mathrm{a}}$ & $13.4^{b}$ & 0.2 \\
\hline Pro & 7.1 & 9.5 & 9.0 & 0.2 \\
\hline Total EAA & $70.8^{\mathrm{a}}$ & $84.2^{\mathrm{b}}$ & $86.6^{b}$ & 2.8 \\
\hline Total NEAA & $81.7^{\mathrm{a}}$ & $99.2^{\mathrm{bc}}$ & $111.1^{\mathrm{c}}$ & 3.4 \\
\hline Total amino acids & $152.5^{\mathrm{a}}$ & $183.4^{\mathrm{bc}}$ & $197.7^{\mathrm{c}}$ & 5.9 \\
\hline
\end{tabular}

$a, b, c$ means in the same row followed by different letters differ at $\mathrm{P}<0.05$

Duodenal NAN flow exceeded daily $\mathrm{N}$ intake in all treatments. Probably it was a result of microbial synthesis in the rumen and recycled endogenous $\mathrm{N}$ and, in the case of SBM+EFB diet, also of a lower extent of ruminal degradability of extruded field bean seeds.

AA profile of protein absorbable in small intestine as well as quantities of individual AA flowing through this part of the gastrointestinal tract are among the most important factors affecting ruminant productivity (Rulquin et al., 1993; Mebjeesh et al., 1996). Researchers are particularly interested in the content, in the protein of small intestine digesta, of two EAA, such as methionine and lysine, which can affect the biological value of dietary protein and can be limiting for lactating dairy cows and goats (Fraser et al., 1991; Bequette et al., 1998; Rulquin et al., 1998). In the case of shecp, sulphur AA (S-AA) - methionine and cystine are 
especially important as they can limit milk yield and its composition, wool production and animal growth (Pisulewski and Buttery, 1985; Cottle, 1988; Urbaniak et al., 1998 ).

The AA profile of duodenal digesta protein is primarily the resultant of the AA composition of microbial protein and dietary protein undegraded in the rumen.

In the study discussed here the content of lysine in the protein of all diets was similar. The amount of this AA was also almost identical in the protein of duodenal digesta of all experimental animals, although its share in the total AA was higher. On the other hand, the content of methionine and cystine varied markedly both in dietary protein as well as in the protein found in the small intestinal digesta. The highest content of these AA in the protein of the SBM+RSM diet $(3.2 \%)$ and the lowest in the SBM+EFB diet $(1.7 \%)$ was associated with the proportion of RSM or EFB in diets. These additives are respectively, either rich or poor in methionine and cystine (Benchaar et al., 1994; Moshtaghi Nia and Ingals, 1995). The content of S-AA in the protein reaching the duodenum increased markedly in all cases, especially, SBM and SBM+EFB dicts ( 2.9 and $2.4 \%$ of crude protein, respectively). This can probably be attributed to the synthesis of microbial protein which is a relatively rich source of methionine and cystine (Santos et al., 1998). Nevertheless, protein of the duodenal digesta of sheep fed the SBM+EFB diet contained the lowest quantity of absorbable S-AA.

Results of the duodenal AA flow are difficult to interpret mainly because of differences in the intake of individual diets. Nonetheless, the highest daily flow of the sum of EAA, NEAA and TAA found in animals fed the SBM+EFB diet, at a simultaneous lower intake of feed in relation to the SBM+RSM diet, points to a higher effectiveness of EFB in the supply of the total AA to the small intestine. At the same time, the flow of S-AA shows clearly that the addition of EFB in conditions of this experiment was a factor limiting the supply of methionine and cystine to the lower gastrointestinal tract of the experimental animals.

\section{CONCLUSIONS}

It can be stated that the source of protein in the ration and the extent of its rumen degradation can affect both the amount and the profile of AA entering the small intestine of sheep. Extruded field bean seeds, which are characterised by a relatively low sulphur AA content and also by a relatively low extent of rumen degradability, can be a factor limiting the supply of methionine and cystine in the protein absorbable in the small intestine. 


\section{REFERENCES}

AOAC, 1990. Association of Official Analytical Chemists. Official Methods of Analysis. 15th Edition. Arlington, VA

Benchaar C., Vernay M., Boyourthe C., Moncoulon R., 1994. Effects of extrusion of whole horse beans on protein digestion and amino acids absorption in dairy cows. J. Dairy Sci. 77, 13601371

Bequette B.J., Backwell F.R.C., Kyle C.E., Calder A.G., Buchan V., Crompton L.A., France J., MacRae J.C., 1998. Vascular sources of phenylalanine, tyrosine, lysine, and methionine for casein synthesis in lactating goats. J. Dairy Sci. 82, 362-377

Clark J.H., Klusmeyer T.H., Cameron M.R., 1992. Microbial protein synthesis and flows of nitrogen fractions to the duodenum of dairy cows. J. Dairy Sci. 75, 2304-2323

Conway E.J., 1962. Microdiffusion Analysis and Volmetric Error. Crosby Lockwood, London

Cotlle D. J., 1988. Effects of defaunation of the rumen and supplementation with amino acid on the wool production of housed Saxo Merinos. Methionine and protected methionine. Aust. J. Exp. Agr. 28, 179-186

Fraser D.L., Ørskov E.R., Whitelaw F.G., Franklin M.F., 1991. Limiting amino acids in dairy cows given casein as the source of protein. Livest. Prod. Sci. 28, 235-252

Henson J.E., Schingoethe D.J., Maiga H.A., 1997. Lactational evaluation of protein supplements of varying ruminal degradabilities. J. Dairy Sci. 80, 385-392

IZ-INRA, 1993. Research Institute of Animal Production. Standarts for Cattle, Sheep and Goat Nutrition (in Polish). Omnitech Press, Warszawa (Poland)

Loerch S.C., Berger L.L., Plegge S.D., Hahey G.C. Jr., 1983. Digestibility and rumen escape of soybcan meal, blood meal, meat and bone meal and dehydrated alfalfa nitrogen. J. Anim. Sci. $57,1037-1047$

Lynch G.P., Jackson C. Jr., Elsasser T.H, Rumsey T.S., Camp M.J., 1991. Nitrogen metabolism of lactating ewes fed rumen-protected methionine and lysine. J. Dairy Sci. 74, 2268-2276

Mabjeesh S.J., Arieli A., Bruckental I., Zamwell S., Tagari H., 1996. Effect of type of protein supplementation on duodenal amino acid flow and absorption in lactating dairy cows. J. Dairy Sci. 79, $1792-1801$

Madsen J., Hvelplund T., 1985. Protein degradation in the rumen. A comparison between in-vivo, nylon bag and buffer measurements. Acta Agr. Scand. 25, Suppl., 103-124

Masoero F., Fiorentini L., Rossi F., Piva A., 1994. Detemination of nitrogen intestinal digestibility in ruminants. Anim. Feed Sci. Tech. 48, 253-262

Mehrez A.Z., Ørskov E.R., 1977. A study of artifical fibre bag technique for determining the digestibility of feeds in the rumen. J. Agr. Sci. 88, 645-650

Metcalf J.A., Wray-Cahen D., Chettle E.E., Sutton J.D., Beever D.E., Crompton L.A., MacRae J.C., Bequette B.J., Backwell F.R.C., 1996. The effect of dietary crude protein as protected soybean meal on mammary metabolism in the lactating dairy cow. J. Dairy Sci. 79, 603-6!1

Moshtaghi Nia S.A., Ingalls J.R., 1995. Influence of moist treatment on ruminal and intestinal disappearance of amino acids from canola meal. J. Dairy Sci. 78, 1552-1560

Pisulewski P.M., Buttery P.J., 1985. The effect of increasing methionine supply on the methionine conversion to cysteine in sheep. Brit. J. Nutr. 54, $121-129$

Price S.G., Satter L.D., Jorgensen N.A., 1988. Dehydrated alfalfa in dairy cow diets. J. Dairy Sci. 71, $727-736$ 
Rulquin H., Guinard J., Verité R., 1998. Variation of amino acid content in the small intestine digesta of calttle: development of a prediction model. Livest. Prod. Sci. 53, 1-13

Rulquin H., Pisulewski P.M., Verité R., Guinard J., 1993. Milk production and composition as a function of postruminal lysine and methionine supply: a nutrient-response approach. Livest. Prod. Sci. 37, 69-90

Santos F.A.P., Santos J.E.P., Theurer C.B., Huber J.T., 1998. Effects of rumen-undgredable protein in dairy cow performance: a 12-year literature review. J. Dairy Sci. 81, 3182-3213

Schwab C.G., 1994. Optimizing amino acid nutrition for optimum yiclds of milk and milk protein. $\ln$ : Proceedings of Southwest Nutrition Manage Conference, Phoenix, University of Arizona, Tuscon, pp. 114-129

Titgemeyer E.C., Marchen N.R., Berger L.L., 1989. Evaluation of soybcan meal, corn giuten meal, blood meal and fish meal sources of nitrogen and amino acids disappearing from the small intestine of steers. J. Anim. Sci. 67, 267-275

Urbaniak M., 1995a. Effects of blood meal, fish meal, soybean meal or casein on rumen protein metabolism in lambs. Small Ruminant Res. 18, 207-212

Urbaniak M., 1995b. Effects of blood meal, fish meal, soybean meal or casein on growth and body composition in lambs. Small Ruminant Res. 18, 213-217

Urbaniak M., Frankiewicz A., Łyczyński A., Pospiech E., Wasilewski Z., Jędroszkowiak P., Matyniak J., 1998. The protein and amino acid content of different body components of Polish Merino $x$ Suffolk rams and ewes at $20 \mathrm{~kg}$ live weight. Rocz. Nauk. Zoot. 25 (4), 105-116

Van Soest P.J., Robertson J.B., Lewis B.A., 1991. Methods of dietary fiber, neutral detergent fiber and non-starch polysaccharides in relation to animal nutrition. J. Dairy Sci. 74, 3583- 3593

\section{STRESZCZENIE}

\section{Wplyw śruty sojowej, rzepakowej i ekstrudowanych nasion bobiku na przeplyw aminokwasów w dwunastnicy owiec}

Przeprowadzono dwa doświadczenia, pierwsze na 4 skopach z kaniulami żwaczowymi, w którym określano stopicń rozkladu w żwaczu białka poekstrakcyjnych śrut: sojowej (SBM) i rzepakowej (RSM) oraz ekstrudowanych nasion bobiku (EFB). Udział $\mathrm{N}$ nie ulegającego rozkładowi $w$ żwaczu w N-ogólnym wynosił odpowiednio $38,29 i 48 \%$.

Drugie doświadczenie wykonano na 4 trykach $z$ kaniulami do dwunastnicy, żywionymi izocnergetycznymi dawkami, składającymi się z siana łąkowcgo i paszy treściwej (50:50), w których główne źródło białka stanowiły odpowiednio SBM, SBM+RSM i SBM+EFB. Największą, statystycznic istotną $(P<0,05)$, zawartość metioniny i cystyny w treści dwunastniczej stwierdzono u owiec żywionych dawką zawierającą SBM+RSM, a najmniejszą u zwierząt otrzymujących SBM+EFB. Największa ilość $(P<0,05) \mathrm{N}$-ogólnego $(33,49 \mathrm{~g} / \mathrm{d})$, N-nicamonowego $(33,08 \mathrm{~g} / \mathrm{d})$, oraz ogólnej sumy aminokwasów $(197,7 \mathrm{~g} / \mathrm{d})$ przepływała u owiec otrzymujących dawkę $\mathrm{SBM}+\mathrm{EFB}$. 